\title{
IMPLEMENTATION OF ROLE PLAYING METHODS BASED ON SOCIAL ISSUES ARROUND STUDENTS TO INCREASE STUDENTS COOPERATION ON SOCIAL RELATIONSHIP IN SOCIAL STUDIES LEARNING
}

\author{
(CLASSROOM ACTION RESEARCH AT CLASS VII-C MUHAMMADIYAH 6 \\ JUNIOR HIGH SCHOOL BANDUNG)
}

\author{
Suci Febriyanti Pertiwi * \\ Muhammadiyah 6 Junior High School Bandung \\ sucifebriyanti18@gmail.com
}

\author{
Mamat Ruhimat \\ Asep Mulyadi
}

\begin{abstract}
The purpose of this research is to increase cooperation among students through the role playing method on the students of class VIII-C Muhammadiyah 6 Junior High School Bandung academic year 2014/2015. This study uses a classroom action research approach. Subjects in this study were students in class VIII-C Muhammadiyah 6 Junior High School Bandung. of collecting data technique using Role Playing method and teacher achievement test. Action is done as much as 3 cycles, in one cycle done 2 times action. Data processing refers to qualitative procedures and changes in learning evaluation results before and after learning by using Role Playing method. The results showed: 1). The percentage of observation results of cooperation between friends on this 1st cycle has not been seen, because it is still within the range of "less" rating with the percentage of $38.1 \%$. While the average learning achievement score of 74.5 , although there is an increase but not showing the expected success rate because the acquisition of values above the minimum score only amounted to 9 people. 2). The result of student activity observation shows that the cooperation between students in cycle 2 is increased, and is in the range of "enough" assessment with the percentage of $68 \%$, the average value obtained is 83.25 , although there is improvement, indicating the expected success rate, there are students earning grades under the minimum score of 4 students. 3). The 3rd cycle shows a very high increase and is in the 'good' range with a percentage of $80 \%$ and an average value of 86 .
\end{abstract}

Keywords: cooperation, role playing

\section{INTRODUCTION}

Based on observations on March 28, 2015 at 14.00 at class VIII-C on Muhammadiyah 6 Junior High School Bandung, it appears that students have no interest to learn or respond to things done by teachers when teaching and learning activities take place. Not a few students who chat and even yawning because of drowsiness. In addition, students look passive when the learning process takes place, no students who ask or respond to what the teacher convey. Everything happens because students have difficulties in understanding social studies materials.

At the beginning of observation, social studies teachers are exploring Social Relations materials using lecture, question and answer methods. During the observation, the researcher observed that in social studies teaching activity the teacher often use one method that is question and answer method. After the teaching activities with the said words it is often followed by frequently asked questions or often used among the implementation of lecture methods or used also for various purposes. Questioning can also be used to understand students' understanding of concepts, generalizations, or subjects. Questions require students to recall information that has been read or heard in class discussions. However, the researcher observed that the questions asked by the teacher to the students were only cognitive statements which were questions about the material explanation that the answer was in the worksheets. The form's question can be categorized as "lower level" . Categorized as low-level questions because students are simply asked to remember or something but do not involve high-level cognitive, application of sisntesis, interpretation, notions of cause and effect, and judgment.

Departure from the above problems and based on the results of initial observations that researchers do in Muhammadiyah 6 Junior High School Bandung, it appears that students lack a sense of togetherness through cooperation, according Sumaatmaja, (1984; 154). Describe cooperation into several dimensions of understanding, Understanding Cooperation According to experts among others

1) An action to achieve common goals or advantages

2) Assistance provided by other people or organizations, groups, or other countries

3) There is a desire to have a cooperative relationship between groups.

Whereas basically the life of cooperation is contained in the social studies lesson but the students do not have action that can benefit for other students, when learning social studies takes place some students do not have a sense of mutual care with other students to build cooperation, students have less emotional relationship in building cooperation in groups on social studies learning. In addition, students look passive when the learning process takes place, no students who ask or respond to what the teacher did and convey. Everything happens because students have difficulties in understanding social studeis materials. The problem found by 
the researcher is one of the problems in the concept of learning in school whereas the school is the central point in forming attitude for all students, this is in line with the opinion of Nasution (124: 1995) that "School is an institution that aims to prepare children to live as community members capable of thinking and doing effective ". In addition, the school should be able to develop students to live together which is accompanied by the principle of spirit of cooperation and social solidarity because in the process of learning a student also needs a sense of security. According to Silberman (24: 2004) "One of the main ways to gain security is to connect with others and be part of a group."

Sumaatmaja, (1984, 20). Explain that social studies Learning aims to develop the potential of students to be sensitive to social problems that occur in the community, have a positive mental attitude towards the improvement of all inequities that occur, and skillfully overcome every problem that occurs everyday that befalls himself and the life of the community.

Thus, it is hoped that social studies can create citizens who have the ability to analyze social problems that occur in the community and can play an active role to participate in the decision-making process and implement social problemsolving decisions. The students are none other than members of the community who must have an awareness of their responsibilities in all manner of deeds in harmony with cultural values so as to create meaningful actions for the benefit of society. This is one of the targets to be achieved in social studeis learning to create students as social beings and people of Indonesia as a whole. In order to improve the cooperation among students in Muhammadiyah 6 Junior High School Bandung in general teachers provide group tasks that are limited to the cognitive aspect only, while the motor aspect and afektinya neglected, in this study researchers used the simulation method, it is more appropriate with the condition of students who tend to prefer to imitate. So researchers use this to educate them by involving the students into the learning that is by the Role Playing method with the aim of an activity that will to grow and train cooperation because in the Role Playing students do not bermin own but play groups that will occur interaction with each others, in addition to their playing, they are also sharpening courage in public. This method will be more memorable in the brain memory of students for the development of knowledge.

Cooperation can be a helping assistance or mutual assistance this aims to strengthen the sense of brotherhood. Besides conducted by individuals or certain groups, cooperation is also conducted between countries. This is related to diplomatic relations to maintain world peace more globally.

Based on the results of initial interviews with students in the field, social studies lesson subjects are viewed as too much theoretical lesson, bored memorization, lacking a contextual example. When teachers give practice questions, most students are lazy to do it, because they have to read in textbooks and do not like to study social studies because they have to accept a long concept. It was found that not all students were able to interact well in the classroom, so the level of cooperation was less, as happened in class VIIIC, there were students who could not interact well with their classmates, so when the teacher assigned the students specially in class VIIIC about learning social relationships to play a role, he did not get a group, it is because the students are less interacting with other friends, there are other reasons caused by the lack of interest in learning from these students so as not to win the trust of his classmates to join in the study group, other factors are the students have a less good attitude in the eyes of his classmates. This makes his friends reluctant to work with these students and make students less confidence during the learning process, so that the motivation to study continues to decrease and make the results of learning in school is not optimal with the values obtained less satisfactory.

Lead from the initial data in the field when the observation that one of the learning methods that can lead to cooperation among students is Role Playing method is one of the learning models for students to try to explore the relationship between humans by demonstrating and discussing so that together students can explore feelings, attitudes, values, and various troubleshooting strategies. As one model of learning, Role Playing can be viewed in terms of personal and social. From a personal point of view, this model helps students to discover the meaning of the social environment that is beneficial to themselves, students are also invited to learn to solve the problems they are facing with the help of a social group of friends of his class. From a social perspective, this model provides an opportunity for students to work together in analyzing social situations. Problem solving is done democratically. Thus with this model students can uphold democratic values.

According to Joyce and Weil (2000: 34) Role-playing is a teaching strategy that belongs to a group of social learning models. This strategy emphasizes the social nature of learning, and considers that cooperative behavior can stimulate students both socially and intellectually.

Role Playing basically has the foundation of a philosophy of contructivism, a learning philosophy that emphasizes that learning is not just memorizing, but constructing new knowledge and skills through the facts or the proportions that they experience in their lives.

By applying the Role Playing model in classroom learning, students are not only able to solve a problem and can work together with their social group, but Role Playing is also able to generate cooperation within a group of classmates. Cooperation is important because it affects socio-cultural change. Social change that covers the attitude of every person and the condition of an environment dominated by differences, so that cooperation must be applied from early on. The way to build the simplest partnership is to respect each other's differences among classmates and not to choose friends in class. Cooperation will be seen during classroom learning by applying Role Playing method, students will join other students to play their respective roles in a story, cooperation among students will be tested in this learning. the actual condition that the cooperation among students is still low then social studies is expected to be the main media in improving cooperation among students.Based on the results of literacy thinking and support by observation results, therefore the author is interested to examine about Implementation Of Role Playing Methods Based On Social Issues Arround Students To Increase Students Cooperation On Social Relationship In Social Studies Learning (Classroom Action Research At Class Vii-C Muhammadiyah 6 Junior High School Bandung). 


\section{METHOD}

In the research to be conducted, researchers use Classroom Action Research. Kemmis (1988) in Vienna Sanjaya (2011: 24), Classroom Action Research is a form of reflective and collective research conducted by researchers in social situations to improve the reasoning of their social practitioners. This method is intended to encourage educators to constantly improve their professionalism, because in practice learning activities, a teacher does not just go to class and teach. However, teachers also need to act as supervisors who can train their ability to evaluate themselves and then act accordingly to their professionalism, so that not only improve their welfare, it is also very important to improve the skills and skills of a teacher. Even McNiff in Ruswandi (2007: 79) views this method as a reflective form done by teachers whose research results can be used as a tool to develop curriculum, school development, development of teaching skills and so on. Therefore, the researcher chose to use this Classroom Action Research as a method in research conducted.

The reason why researchers choose Classroom Action Research research methods is based on the characteristics of the Classroom Action Research itself. Wardhani (2007: 15-17) found that the characteristics this method is First, the emergence of a self-awareness of the teacher that the learning he has been doing in the class has problems that need to be solved; Second, selfreflective inquiry or research through selfreflection; Third, the method is done in the classroom, so the focus of this study is learning activities in the form of teacher and student behavior in interaction; Fourth, Classroom Action Research aims to improve learning. A class that has problems in it is certainly caused by various things that can be caused by the teacher in this case the use of methods or learning models that have not been right or caused by the students. When that happens then the most appropriate problem-solving method is through the use of the Classroom Action Research method because the method is implemented in the classroom in order to improve the problematic learning process. This research uses model of Classroom Action Research from Model Kemis and Mc Taggart in Wiriatmadja (2009, pp. 66), which consists of: planning, execution, observation and reflection. The subject of research is the students of class VII-C Muhammadiyah 6 Junior High School Bandung.

In this study, the researcher serves as a teacher collaborating with partner teachers and peers who served as observers and discussion partners during the study. The data collection technique is done through observation, interview, field / daily notes and documentation. The collected data is then processed by analyzing the observation matrix, field notes, wawncara results and documentation. Further data are analyzed through the following steps: data reduction, data display, conclusing drawing / verivication. In order for data obtained from the field is valid, then done in various ways, namely: triangulation, member chek, audit trail, and expert opinion.

\section{RESULTS AND DISCUSSION}

1. Planning Implementation of Role Playing Method Based on Social Issues Around Students To Increase Inter-Student Cooperation In Social Relation Subject Matter on Social Studies Lesson
Planning stage is an important stage to be implemented so that learning activities can run in accordance with what is expected. At the planning stage the researcher prepares the best possible things related to the course of the research. Researchers conduct discussions with partner teachers and supervisors as more experienced parties. Many inputs or suggestions from partner teachers and supervisors in the planning process so that actions can be implemented in accordance with the objectives to be achieved. Based on the results of preliminary observations made by researchers that can know the low skills of information literacy students in learning social studies in class VII-C. Therefore the researchers do the planning to apply the role playing method in IPS learning as an effort to improve cooperation among students.

Furthermore, the researcher develops the learning implementation plan covering the objectives to be achieved, the material that will be submitted to support the research, the media of interest for the students and the assessment instrument in the form of observation guidance and field notes. The learning steps are designed as well as possible by using role playing method in order to increase cooperation among students. Researchers arrange learning step by using role playing method. According to Joyce and Weil (2000: 34) Role-playing is a teaching strategy that belongs to a group of social learning models. This strategy emphasizes the social nature of learning, and considers that cooperative behavior can stimulate students both socially and intellectually. The learning steps will affect the success of the course of research when the action takes place. Therefore, the preparation of the implementation plan of learning is very important to do before the learning process is implemented.

At the planning stage the researchers set up a research instrument to measure cooperation among students. Indicators of improving student cooperation by using role playing method are based on the literature that has been studied by the researcher and adapted to the existing characteristics in the field. The preparation of this research instrument is conducted to facilitate the researcher in observing the learning activities during the research.

Each cycle of researchers comprises an Learning Implementation Plan that supports the ongoing action in the research. Preparation of the Learning Implementation Plan is also discussed with partner teachers so that the course of this research can not be separated from the support of partner teachers. Learning Implementation Plan should be arranged as best as possible so that it can be used as material to carry out the action in the research. Learning Implementation Plan is designed based on the method used is the role playing method and adapted to the applicable curriculum. Learning Implementation Plan is prepared and designed well then the learning process will be more directed and well structured so that the preparation and design of Learning Implementation Plan before the learning activities implemented is very important.

2. Aplication of Implementation of Role Playing Method Based on Social Issues Around Students To Increase InterStudent Cooperation In Social Relation Subject Matter on Social Studies Lesson. 
This study was conducted with three cycles. The teacher's first cycle provides brief briefing and explanation of material on Social Relations. Explanation of the material that just as bait or stimulus for students is something that the teacher deliberately do so later when going to the next stage whether students will be able to find information that has not been completed submitted by the teacher. The step is done as an effort to improve cooperation among students. After a little material explanation is sufficient, the teacher directs the students to form a role-playing group with the theme according to the subject matter of Social Relations. The themes given to each group vary so that the roles displayed by the students vary.

Based on observations made by researcher and partner teacher in assessing student activity, it can be seen that the cooperation among students in this research has not been seen, because it is still in the range of "less" rating with $33.3 \%$ percentage. The more detailed explanation according to the indicators of student learning cooperation are as follows:

\section{Action}

Implementation of Social Studies learning through the application of role-playing methods, still can not improve actions that can benefit other students in the group. Particularly in preparing the scenarios to be played, only a fraction of the number of students is able to act and benefit other students. Students also appear to be less able to perform individual tasks well, it can be seen from only a few students who do their job well, neatly and earnestly in doing the task. Aside from that. Although there are other students who have done the task, but still less in completion of the task.

\section{Help each other}

Based on the implementation of the action in the first cycle, the attitude of mutual assistance is still less visible in the learning activities of social studies in the classroom. It can be seen from the many students who do not care to the students in the good linnya, it shows that students are less able to cooperate and impressed indiviualis, especially when the tasks assigned by teachers are felt enough to do the task. Then, when the lesson takes place, there are still many students who ask whether the material presented by the teacher is written or not in the notebook, the students who already know do not want to give an explanation or tell it.

\section{Relationships}

In this first cycle, the student's relationship in improving cooperation is still within the range of "less" assessment, where there are still many students in unharmonious relationships with other students that happening with each other bully and mock each other shows that the relationship between students is still relatively less in building cooperation

The second cycle is not so different from the first cycle. In this second cycle a little different is all the preparation becomes more mature again, such as group members who have gathered with his group before the learning activities so that the allocation of time became more effective and efficient.

Based on observations made by partner teachers in assessing student activity it is seen that the cooperation between students in cycle 2 is increasing very high, and is in the range of "good" rating with the percentage of $88.8 \%$. The more detailed explanation according to the indicators of student learning cooperation are as follows:

\section{Action}

Implementation of IPS learning through the application of role-playing methods, has been able to improve actions that can benefit other students in the group. Particularly in preparing scenarios to be played, most are each capable of acting and benefiting other students. Students are also able to perform tasks individually well, it can be seen from most students who do their job well, neatly and seriously in doing the task.

\section{Help each other}

Based on the implementation of the action in the second cycle the attitude of mutual help is seen to increase in the learning activities of social studies in the classroom. It can be seen that students who have a sense of care terhdap students linnya it shows that students are able to cooperate and seem to getong royong.

\section{Relationships}

In this cycle, the student's relationship in improving cooperation is within the "Good" rating range, where many students are in close relationship with other students and even look at each other's attention

Based on observations made by partner teachers in assessing student activity it is seen that the cooperation among students in cycle 3 is increasing very high, and is in the range of "good" rating with the percentage of $99 \%$. The more detailed explanation according to the indicators of student learning cooperation are as follows:

\section{Action}

Implementation of IPS learning through the application of role-playing methods, has been able to improve actions that can benefit other students in the group. Particularly in preparing scenarios to be played, most are each capable of acting and benefiting other students. Students are also able to perform tasks individually well, it can be seen from most students who do their job well, neatly and seriously in doing the task.

\section{Help each other}

Based on the implementation of the action on the cycle kemau mutual help seems to increase in the learning activities of social studies in the classroom. It can be seen that students who have a sense of care terhdap students linnya it shows that students are able to cooperate and seem to getong royong.

\section{Relationships}

In this third cycle, the relationship among fellow students in improving cooperation is within the "Good" rating range, in which many students are in close relationship with other students and even look mutual.

In this discussion the researcher will discuss about the implementation of role playing method in increasing cooperation among students in social studies learning conducted in class VIII-C Muhammadiyah 6 Junior High School Bandung, data from research results according of 
activities as much as 3 cycles in each cycle is done 2 times action. In this research there are 3 indicators with 6 sub indicators that become acan for research success in increasing cooperation in Social Studies learning both individually and group. Below can be seen table of percentage results in cycles 1 and 2 which then converted into the form of less value (1), Enough (2), Good (3):

Table 4.13

The results of the percentage of cooperation among friends on IPS learning

\begin{tabular}{|c|c|c|c|}
\hline $\begin{array}{c}\text { Implementation of } \\
\text { activities }\end{array}$ & Score & $\begin{array}{c}\text { Percentage of } \\
\text { cooperation }\end{array}$ & Category \\
\hline Cyclus 1 & 247 & $38.1 \%$ & Enough \\
\hline Cyclus 2 & 441 & $68 \%$ & Good \\
\hline Cyclus 3 & 501 & $80 \%$ & Good \\
\hline
\end{tabular}

Percentage of cooperation between friends $=\underline{\text { score }}$ obtained x 100

Maximum score

Average Conversions (percentage)

\begin{tabular}{|l|l|}
\hline Score & Percentage Score \\
\hline Less & $0 \%-33.3 \%$ \\
\hline Enough & $33.4 \%-66.7 \%$ \\
\hline Good & $66.8 \%-100 \%$ \\
\hline
\end{tabular}

Komalasari Resources (2010: 156)

Based on the above table it can be seen that the cooperation between peer group in Social Studies learning has significant improvement from cycle 1 to cycle 2 , in the first cycle the percentage shows $38.1 \%$ meaning that the cooperation between the friends is still considered enough but the numbers are close to the less category and in the second cycle 2 a very significant increase by obtaining a $68 \%$ presenase in the good category and an increase of $29.9 \%$. and from cycle 2 to cycle 3 the following $80 \%$ is a graph of improving the improvement of cooperation between friends with the application of role playing methods.

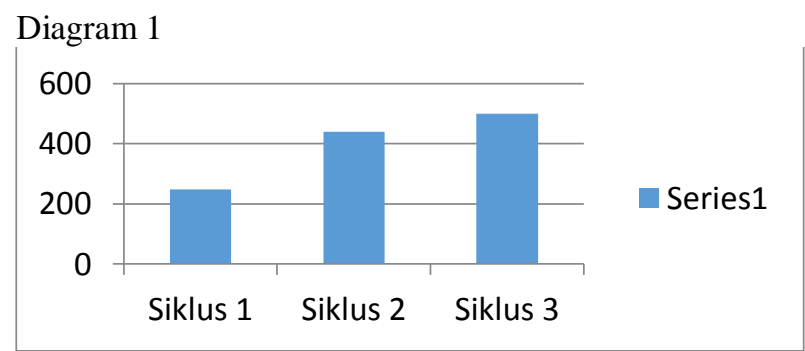

Research data source 2015

From the results of the above data prsentase shows that the cooperation between friends in social studies learning has increased in each cycle. In the 1 st cycle of cooperation between friends are in the category enough but close to the category less with a percentage of $38.1 \%$, and on the second cycle has increased very significantly and is in good category with $68 \%$ prsentase. Then in the 3rd cycle reached $80 \%$ Based on the results of the study illustrated that there is a significant increase.
3. Obstacles and solutions in implementing Role Playing Method Based Social Issues Around Students To Improve Inter-Student Cooperation In Social Relation Subject Matter on Social Studies Lesson

During the course of the implementation of this study certainly can not be separated from the constraints and problems experienced. Researchers found obstacles during the study. Obstacles experienced if repaired it will affect the achievement of research objectives. Obstacles experienced can occur due to various things that are not even predicted by researchers. The following obstacles experienced in the application of role playing method to improve cooperation among students in social studies learning is that students have never used the role playing method so that in the first cycle students are still confused; students are not fully willing to carry out some learning activities using the role playing method due to lack of confidence and feel the fear of wrong and class conditions that are not conducive when students are playing the role that makes concentration to be disturbed.

The above obstacles that researchers find to influence the achievement of research objectives. These barriers occur outside the predicted researchers. Preventing these obstacles from happening again, researchers can reflect on the experience and preparation of better and more mature planning. Researchers also need to develop alternative ways to overcome these obstacles do not happen again. Obstacles that are found can hinder the purpose of research that has been planned. It shows the constraints that occur affect the course of research into the future. After the action in the research carried out, researchers always do reflection with several parties. The reflection stage is done by the researcher by discussing with the partner's teacher. Reflection is done to identify the obstacles that occur as well as find ways to prevent these barriers in subsequent action. The following solutions to the obstacles in implementing the application of role playing methods to improve cooperation among students in social studies learning is that teachers should explain the role playing method clearly. Researchers can also look for video application of the role playing method so that before applying the method students first see the learning steps using the role playing method. Video views will make it easier for students to understand how the role playing method works; teachers need to provide materials that build curiosity in order to stimulate students and then approach the students and more direct students to want to try to follow the learning activities and management of the class needs to be improved and then maintained. Teachers should be more assertive in conditioning students who do not pay attention when the learning activities take place or the teacher enforces the rules for students who perform activities outside of learning activities.

\section{CONCLUCION}

Based on the results of research in class VIII-C Muhammadiyah 6 Junior High School Bandung, the cooperation between students is still not established especially in learning social studies, visible students have no interest or respond to things done by teachers when teaching and learning activities take place. Social studies learning is considered boring by students because it is considered theoretical learning 
and bored memorize, so students are not too concerned. Cooperation is less intertwined among students make learning passive, whereas basically in the social studies learning cooperation is one unity, because as a learning subject social studies is expected to grow the attitude of cooperation among students because not only a science given to students but also mempu make provision of students later to live in society and make good citizens who are able to appreciate each other, mutual cooperation which has become the hallmark of Indonesian people. Therefore, the researcher and the partner teacher tried to apply Role Playing method as a way to improve cooperation among students especially in class VIIIC Muhammadiyah 6 Junior High School Bandung City, with 3 cycles which each done with 2 actions. Role Playing method is considered able to increase cooperation among students because therein there is a learning that requires students to play roles in groups to play a drama according to their respective roles, and there is coordination among group friends, so that intertwined communication, interaction, mutual trust and mutual cooperation make students cooperate with their group. From the application of Role Playing method in class VIII-C Muhammadiyah 6 Junior High School Bandung, there are significant changes from per cycle. The results showed: 1). The percentage of observation results of cooperation between friends on this 1 st cycle has not been seen, because it is still within the range of "less" rating with the percentage of $38.1 \%$. While the average learning achievement score of 74.5, although there is an increase but not showing the expected success rate because the acquisition of values above the minimum score only amounted to 9 people. 2). The result of student activity observation shows that the cooperation between students in cycle 2 is increased, and is in the range of "enough" assessment with the percentage of $68 \%$, the average value obtained is 83.25 , although there is improvement, indicating the expected success rate, there are students earning grades under the minimum score of 4 students. 3 ). The 3 rd cycle shows a very high increase and is in the range of 'good' with a percentage of $80 \%$ and an average value of 86 . Therefore Role Playing method is very appropriate to be used in learning social studies to improve cooperation among students, especially in class VIII -C Muhammadiyah 6 Junior High School Bandung.

\section{BIBLIOGRAPHY}

Achmadi, A. dan Nurboko, C. (2003). Metodologi Penelitian. Jakarta : Bumi Aksara.

Arifin, Zainal (2009). Evaluasi guruan. Bandung : PT Remaja Rosdakarya.

Arifin, Daeng, (2010). Manajemen Pembelajaran Efektif. Bandung : Pustaka Alkasyaf

DeVito. Joseph.A. 1997. Komunikasi Antarmanusia : Kuliah dasar ( Edisi Kelima). Alih Bahasa Oleh Agus maulana MSM. Jakarta : Profesional Books.

Hermawan, Hendy (2006). Dasar - Dasar Komunikasi dan Keterampilan Mengajar. Bandung : CV Citra Praya.

Majid, Abdul, (2009). Perencanaan Pembelajaran.

Bandung : PT Remaja Rosdakarya.

Mudjiono dan Dimyati, (2002). Belajar dan Pembelajaran.

Jakarta : PT. Rineka Cipta.
Suyono dan Hariyanto, (2011). Belajar dan Pembelajaran Teori dan Konsep Dasar. Bandung : PT Remaja Rosdakarya.

Wardhana, Yana, (2010). Teori Belajar dan Pembelajaran. Bandung : Pribumi mekar.

Mulyasa, (2009). Prakti Penelitian Tindakan Kelas. Bandung : Rosda karya.

Wardhani, Igak. (2007). Penelitian Tindakan Kelas. Jakarta : Universitas Terbuka.

Wiriaatmadja, R. (2009) Metode Penelitian Tindakan Kelas. Bandung : Remaja Rosdakarya. 